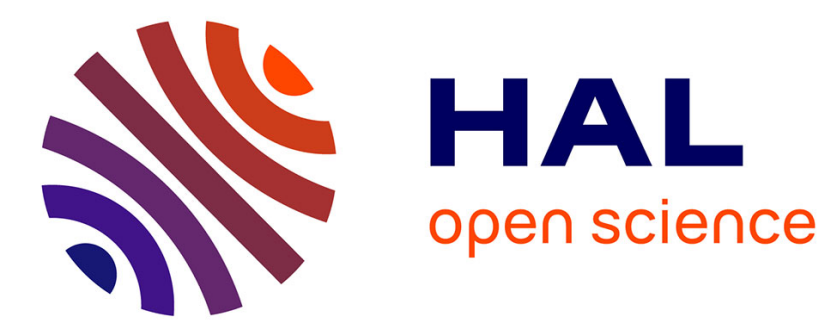

\title{
The thiocyanate anion as a polydentate halogen bond acceptor
}

Pascal Cauliez, Victor Polo, Thierry Roisnel, Rosa Llhusar, Marc Fourmigué

\section{To cite this version:}

Pascal Cauliez, Victor Polo, Thierry Roisnel, Rosa Llhusar, Marc Fourmigué. The thiocyanate anion as a polydentate halogen bond acceptor. CrystEngComm, 2010, 12, pp.558-566. 10.1039/b913559f . hal-00468289

\section{HAL Id: hal-00468289 \\ https://hal.science/hal-00468289}

Submitted on 15 Jul 2013

HAL is a multi-disciplinary open access archive for the deposit and dissemination of scientific research documents, whether they are published or not. The documents may come from teaching and research institutions in France or abroad, or from public or private research centers.
L'archive ouverte pluridisciplinaire HAL, est destinée au dépôt et à la diffusion de documents scientifiques de niveau recherche, publiés ou non, émanant des établissements d'enseignement et de recherche français ou étrangers, des laboratoires publics ou privés. 


\title{
The thiocyanate anion as a polydentate halogen bond acceptor $\dagger$
}

\author{
Pascal Cauliez, ${ }^{a}$ Victor Polo, $\oiint^{b}$ Thierry Roisnel, ${ }^{a}$ Rosa Llusar ${ }^{b}$ and Marc Fourmigué ${ }^{\star a}$
}

\author{
Received 8th July 2009, Accepted 16th September 2009 \\ First published as an Advance Article on the web 2nd October 2009 \\ DOI: 10.1039/b913559f
}

Co-crystallisation of the $\mathrm{Et}_{4} \mathrm{~N}^{+}$or $n-\mathrm{Bu}_{4} \mathrm{~N}^{+}$salts of the thiocyanate anion with $o-, m$ - and p-diodoperfluorobenzene or the sym-trifluorotriiodobenzene allowed for the isolation of six different salts which were structurally characterized by single crystal X-ray diffraction. Halogen bonding interactions are observed between the neutral iodinated molecules acting as halogen bond donors and the $\mathrm{S}$ or $\mathrm{N}$ ends of the thiocyanate anion, with a variety of bonding modes (terminal as well as bridging), and characterised by short $\mathrm{I} \cdots(\mathrm{N}, \mathrm{S})$ contacts and linear $\mathrm{C}-\mathrm{I} \cdots(\mathrm{N}, \mathrm{S})$ motifs. On the other hand, the $\mathrm{I} \cdots$ $\mathrm{N} \equiv \mathrm{C}$ angles present deviations from linearity $\left(145-170^{\circ}\right)$ while the $\mathrm{I} \cdots \mathrm{S}-\mathrm{C}$ angles are close to $90^{\circ}$, revealing a type II halogen bond interaction with the $\mathrm{S}$ atom acting as pseudo halogen. The observation of structures where only the $\mathrm{S}$ or the $\mathrm{N}$ atom are engaged in halogen bonding suggests that the two coordination modes are close in energy, as confirmed by DFT calculations and ELF analysis which give also a rationale for the observed structural preferences. This bidentate nature of the $\mathrm{SCN}^{-}$anion in halogen bonding interactions is reminiscent of its various coordination modes with the $\mathrm{Cd}^{2+}$ cation, best understood in terms of the hard-soft acid-base concept.

\section{Introduction}

Halogen bonding in the solid state, albeit known for many years, ${ }^{1}$ is currently the subject of an intense research effort. ${ }^{2}$ It describes a directional, attractive interaction between covalently bound halogen atoms and Lewis bases and exhibit many similarities with hydrogen bonding, ${ }^{3}$ with which it can even successfully compete. ${ }^{4}$ The electrostatic contributions to this interaction result from the anisotropic charge distribution around the halogen, with a positive potential that develops at the halogen in the region trans to the $\mathrm{C}-\mathrm{X}$ bond, ${ }^{5,6}$ a region which then plays a role similar to the hydrogen atom in hydrogen bonding. The effects are strongest with the heaviest, most polarisable halogens $(\mathrm{Br}, \mathrm{I})$ and are further enhanced when electron-withdrawing groups are attached to the carbon atom. This directional interaction thus appears as an efficient tool for supramolecular chemistry and crystal engineering, and has been extensively developed in the last ten years by Resnati and Metrangolo, ${ }^{7,8}$ who used iodoperfluorocarbon molecules as halogen bond donors, facing them with a broad range of organic Lewis bases. ${ }^{9}$ Other efficient halogen bond acceptors were found in metal complexes with terminal ligands such as halide, oxo or nitrido groups but also carbonyl or cyanide ones, as recently reviewed by Brammer. ${ }^{10}$ In many cases, the investigated interactions involved neutral donor and acceptor molecules. Since the halogen bond interaction is essentially of electrostatic origin, one

\footnotetext{
${ }^{a}$ Sciences Chimiques de Rennes, Université Rennes1, UMR CNRS 6226, Equipe MaCSE, Bât 10C, Campus de Beaulieu, 35042 Rennes, France. E-mail: marc.fourmigue@univ-rennes1.fr

${ }^{b}$ Departament de Química Física i Analitica, Universitat Jaume I, Avda. Sos Baynat s/n, 12080 Castelló, Spain

$\uparrow$ CCDC reference numbers 739580-739585. For crystallographic data in CIF or other electronic format see DOI: 10.1039/b913559f

* Permanent address: Departamento de Química Orgánica y Química Física, Universidad de Zaragoza, c/Pedro Cerbuna s/n, 50009 Zaragoza, Spain.
}

can easily anticipate that charge assistance in salts might strongly increase its strength, provided that the positive charge is on the halogen bond donor moiety, the negative charge on the halogen bond acceptor moiety. ${ }^{11}$ Such electrostatic effects have been clearly evidenced (i) in pyridinium salts with the halogen atom on the pyridine ring acting as halogen bond donor, ${ }^{12,13}$ (ii) in cation radical salts of halogenated tetrathiafulvalenes with the halogen atom interacting with the counter ion such as halides, ${ }^{14}$ polyhalides $\left(\mathrm{I}_{3}{ }^{-}\right.$, $\left.\mathrm{IBr}_{2}^{-}, \ldots\right)$, halometallates or cyanometallates such as $\left[\mathrm{Ag}(\mathrm{CN})_{2}\right]^{-}$or $\left[\mathrm{Ni}(\mathrm{CN})_{4}\right]^{2-} \cdot{ }^{15}$ In these situations, extremely short intermolecular distances between the halogen atom and the Lewis base were indeed observed, confirming also the strong electrostatic contribution to the interaction.

The intermediate situation where the halogen bond donor molecule is neutral while the halogen bond acceptor is anionic has been also investigated and iodinated conjugated molecules such as diiodoacetylene, tetraiodoethylene, perfluoro mono or di-iodobenzene have been shown ${ }^{16,17}$ to form extended networks when associated with halide anions $\left(\mathrm{Cl}^{-}, \mathrm{Br}^{-}, \mathrm{I}^{-}\right)$. Similar structures were also reported with the sym-trifluoro-triiodobenzene. ${ }^{18,19}$ This topic of anion coordination and anion-templated assembly under halogen bonding control has been very recently reviewed. ${ }^{20} \mathrm{~A}$ beautiful extension of this work was reported by Metrangolo and Resnati with neutral ditopic molecules capable of simultaneous binding of both the anion (through halogen bonding) and the cation (with a crown ether moiety) of simple salts. ${ }^{21}$ Non-conjugated iodoperfluoroalkanes also proved to be very efficient ${ }^{22}$ as exo-receptors for naked anions while $\mathrm{CBr}_{4}$ was successfully engaged with dibromocuprate salts. ${ }^{23}$ In most cases, the halide anion is able to halogen-bond to several donor molecules (up to four) simultaneously, affording polymeric networks with various connectivities and dimensionalities. ${ }^{7,20}$ Such polymeric anionic networks were also included by Yamamoto and Kato in electro-crystallization experiments with non-halogenated tetrathiafulvalenium salts to afford ternary 
systems incorporating the partially oxidized donor molecules, and the anionic networks comprised of halide anions halogen bonded to neutral iodinated molecules. ${ }^{24,25}$

Most examples described so far of such halogen interactions with this neutral donor/anionic acceptor scheme concerned simple halide anions. ${ }^{19} \mathrm{~F}$ NMR investigations ${ }^{22}$ of the upfield shift shown by the $-\mathrm{CF}_{2} \mathrm{I}$ signal of 1,2-diiodotetrafluorethane (I- $\mathrm{CF}_{2} \mathrm{CF}_{2}-\mathrm{I}$ ) upon addition of a three-fold excess of various anions $\left(\mathrm{I}^{-}, \mathrm{Br}^{-}, \mathrm{Cl}^{-}, \mathrm{NO}_{3}^{-}, \mathrm{SCN}^{-}, \mathrm{CN}^{-}\right)$showed that the strongest effect of halogen bonding were indeed observed with the most polarisable $\mathrm{I}^{-}$anion while the $\mathrm{SCN}^{-}$anion appeared as a much weaker halogen bond acceptor, within the series $\mathrm{I}^{-}>\mathrm{Br}^{-}>\mathrm{Cl}^{-}>\mathrm{CN}^{-}>\mathrm{SCN}^{-}>\mathrm{NO}_{3}{ }^{-}$. The ability of the thiocyanate anion to interact with halogen bond donors in the solid state was however recently demonstrated by Bock and Holl, who described its halogen bonding interaction with neutral donor molecules bearing four iodine atoms, that is tetraiodoethylene, ${ }^{26}$ tetraiodothiophene ${ }^{27}$ and $\mathrm{N}$-methyltetraiodopyrrole ${ }^{28}$ (Scheme 1). Analyses of the three crystal structures revealed for the $\mathrm{SCN}^{-}$anion a bitopic character, with both the nitrogen and the sulfur atoms engaged in halogen bonding interaction with these poly-iodo conjugated molecules. On the other hand, Kochi reported that the crystallization of $n \mathrm{Bu}_{4} \mathrm{NSCN}$ with $\mathrm{CBr}_{4}$ affords a 1:1 complex where $\mathrm{CBr}_{4}$ is halogen bonded only to the sulfur atom while the nitrogen atom is "free". ${ }^{29}$ As an element of comparison, hydrogen bonded systems to the $\mathrm{SCN}^{-}$anion were shown by Guru Row et al. to involve both the nitrogen and the sulfur atoms in its ammonium salts. ${ }^{30}$

The $\mathrm{SCN}^{-}$salts mentioned above exhibit several remarkable peculiarities, that is (i) unexpected strong deviations from linearity for the $\mathrm{C} \equiv \mathrm{N} \cdots \mathrm{I}$ angles, (ii) presence of several iodine atoms "coordinating" the sulfur one and (iii) acute $\left(91-100^{\circ}\right) \mathrm{C}-\mathrm{S} \cdots \mathrm{I}$ angles. In our recent investigations of the halogen bonding interaction of halide anions $\left(\mathrm{Cl}^{-}, \mathrm{Br}^{-}\right)$with the 1,3,5-trifluoro2,4,6-triiodobenzene, ${ }^{18}$ a detailed topological analysis of the electron localization function ${ }^{31,32}$ (ELF) had shown a perfect match between the organic iodine valence shell electrons, with a "belt"-shape arrangement around the $\mathrm{C}-\mathrm{I}$ axis, and the spherical halide anions $\left(\mathrm{Cl}^{-}, \mathrm{Br}^{-}\right)$. We wanted to apply the same theoretical analysis on the thiocyanate anion as halogen bond acceptor in order to possibly rationalise the actual geometries found in the solid state. As halogen bond donors, besides the examples shown in Scheme $1^{26-28}$ or molecules like $\mathrm{CBr}_{4},{ }^{29}$ other iodo-aromatics activated with fluorine atoms such as $o-, m$ - or $p$ diodoperfluorobenzene or the sym-trifluorotriiodobenzene ${ }^{18,19,33}$ (Scheme 2) have proven very efficient halogen bond donors, towards pyridines, amines as well as halide anions. They have been faced here with the $\mathrm{SCN}^{-}$anion, in order to expand the available library of thiocyanate salts engaged in halogen bonding in the hope to observe some recurrent geometrical trends in association with activated iodine atoms.
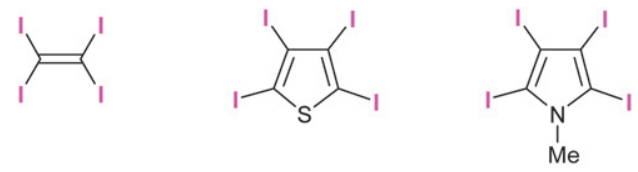

Scheme 1<smiles>CCOc1c(F)c(F)c(I)c(F)c1I</smiles><smiles>Fc1c(F)c(F)c(I)c(I)c1F</smiles><smiles>Fc1c(F)c(F)c(I)c(F)c1F</smiles><smiles>Fc1c(I)c(I)c(F)c(I)c1I</smiles>

Scheme 2

We describe here six novel thiocyanate salts, as $\mathrm{Et}_{4} \mathrm{~N}^{+}$or $n-\mathrm{Bu}_{4} \mathrm{~N}^{+}$salts, with these perfluoroiodobenzene derivatives, and analyse their solid state characteristics, with an emphasis on the halogen bond patterns they adopt, while a rationale is provided by a detailed topological analysis of the electron localization function (ELF) ${ }^{34}$

\section{Results and discussion}

\section{Crystal growth and structure analysis}

Either the $\mathrm{Et}_{4} \mathrm{~N}^{+}$or the $n-\mathrm{Bu}_{4} \mathrm{~N}^{+}$thiocyanate salts were mixed in a 1:1 ratio with either the $o-, m$ - or $p$-diodoperfluorobenzene or the sym-trifluorotriiodobenzene (Scheme 2). Concentration and cooling of the solutions afforded crystalline material (Table 1) in six out of the eight investigated systems, since $n$ - $\mathrm{Bu}_{4} \mathrm{NSCN}$ with $o$ - and $m$-diodoperfluorobenzene did not afford in our hands any crystalline material but oils. The actual stoichiometry of the salts was deduced from elemental analyses and single-crystal X-ray diffraction experiments. They exhibit different stoichiometries (Table 1) despite a starting 1:1 composition. They will be described in the following according to the structural motifs they develop in the solid state.

\section{The thiocyanate anion as a bidentate anion in $3 \mathrm{~b}, 4 \mathrm{a}$ and $4 \mathrm{~b}$}

Salt 3b adopts a 1:1 stoichiometry and is formulated as $\left(n-\mathrm{Bu}_{4} \mathrm{NSCN}\right)\left(p-\mathrm{C}_{6} \mathrm{~F}_{4} \mathrm{I}_{2}\right)$. It crystallises in the monoclinic system, space group $P 2{ }_{1} / n$, with the anion, the cation and the neutral $p-\mathrm{C}_{6} \mathrm{~F}_{4} \mathrm{I}_{2}$ molecule in general position in the unit cell. Molecules of $p-\mathrm{C}_{6} \mathrm{~F}_{4} \mathrm{I}_{2}$ are separated from each other by the bulky tetrabutylammonium groups and the shortest intermolecular I $\cdots \mathrm{I}$ contacts exceed $4.7 \AA$. On the other hand, they are associated into chains running along $b$ (Fig. 1), through coordination of both the nitrogen and the sulfur atoms of the $\mathrm{SCN}^{-}$anion.

The structural characteristics of these two halogen bonding interactions are collected in Table 2 and point to strong interactions as the $\mathrm{I} \cdots \mathrm{N}$ and $\mathrm{I} \cdots \mathrm{S}$ intermolecular distances are particularly short when compared with the sum of the van der

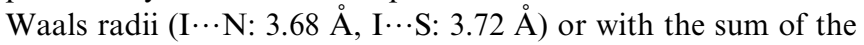

Table 1 Isolated compounds and their formulation

\begin{tabular}{lllll}
\hline & $o-\mathrm{C}_{6} \mathrm{~F}_{4} \mathrm{I}_{2}$ & $m-\mathrm{C}_{6} \mathrm{~F}_{4} \mathrm{I}_{2}$ & $p-\mathrm{C}_{6} \mathrm{~F}_{4} \mathrm{I}_{2}$ & $s y m-\mathrm{C}_{6} \mathrm{~F}_{3} \mathrm{I}_{3}$ \\
\hline $\mathrm{Et}_{4} \mathrm{NSCN}$ & $\mathbf{1 a}, 1: 2$ & $\mathbf{2 a}, 1: 1$ & $\mathbf{3 a}, 2: 5$ & $\mathbf{4 a , 1} 1: 1$ \\
& $\left(\mathrm{Et}_{4} \mathrm{NSCN}\right)$ & $\left(\mathrm{Et}_{4} \mathrm{NSCN}\right)$ & $\left(\mathrm{Et} \mathrm{NSCN}_{4} \mathrm{NSCN}_{2}\right.$ & $\left(\mathrm{Et} \mathrm{NSCN}_{4} \mathrm{NSCN}\right)$ \\
& $\left(o-\mathrm{C}_{6} \mathrm{~F}_{4} \mathrm{I}_{2}\right)_{2}$ & $\left(m-\mathrm{C}_{6} \mathrm{~F}_{4} \mathrm{I}_{2}\right)$ & $\left(m-\mathrm{C}_{6} \mathrm{~F}_{4} \mathrm{I}_{2}\right)_{5}$ & $\left(s y m-\mathrm{C}_{6} \mathrm{~F}_{3} \mathrm{I}_{3}\right)$ \\
& & - & $\mathbf{3 b}, 1: 1$ & $\mathbf{4 b}, 2: 1$ \\
& & & $\left(n-\mathrm{Bu}_{4} \mathrm{NSCN}\right)$ & $\left(n-\mathrm{Bu}_{4} \mathrm{NSCN}\right)_{2} \mathrm{NSCN}$ \\
& & & $\left(p-\mathrm{C}_{6} \mathrm{~F}_{4} \mathrm{I}_{2}\right)$ & $\left(s y m-\mathrm{C}_{6} \mathrm{~F}_{3} \mathrm{I}_{3}\right)$ \\
\hline
\end{tabular}




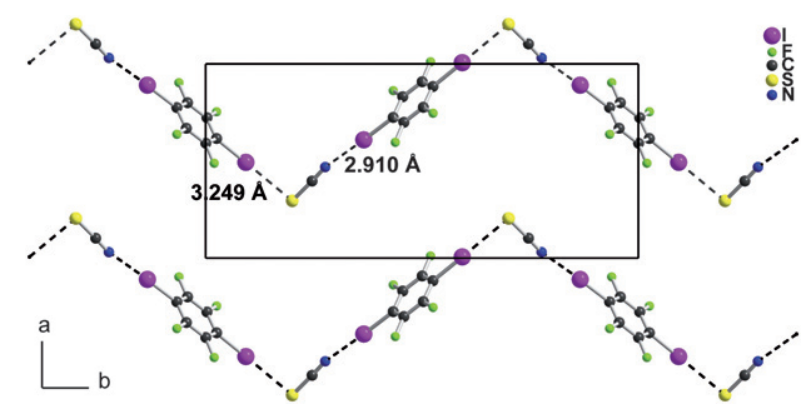

Fig. 1 A view of the chains formed by the ditopic $p-\mathrm{C}_{6} \mathrm{~F}_{4} \mathrm{I}_{2}$ molecules and the $\mathrm{SCN}^{-}$anion in $\mathbf{3 b}$.

non-isotropic radii developed by Nyburg and Faerman ${ }^{35}\left[r_{\min }(\mathrm{I})\right.$ $+r_{\text {max }}(\mathrm{N})=1.76+1.60=3.36 \AA ; r_{\text {min }}(\mathrm{I})+r_{\text {max }}(\mathrm{S})=1.76+2.03$ $=3.79 \AA]$. Furthermore, these chains exhibit structural features which are characteristic of the other examples described below, that is a relatively linear $\mathrm{I} \cdots \mathrm{N} \equiv \mathrm{C}$ contact which contrasts with the acute $\mathrm{I} \cdots \mathrm{S}-\mathrm{C}$ angle close to $90^{\circ}$. This structure represents the best possible adaptation between the symmetric, ditopic $p-\mathrm{C}_{6} \mathrm{~F}_{4} \mathrm{I}_{2}$ halogen bond donor molecule and the ditopic, unsymmetric $\mathrm{SCN}^{-}$halogen bond acceptor anion.

Salt 4a adopts the same 1:1 stoichiometry, with one $\mathrm{Et}_{4} \mathrm{NSCN}$ for one tritopic sym- $\mathrm{C}_{6} \mathrm{~F}_{3} \mathrm{I}_{3}$ molecule. It crystallises in the monoclinic system, space group $P 2_{1} / n$ with the three entities in general position in the unit cell (Fig. 2). The $s y m-\mathrm{C}_{6} \mathrm{~F}_{3} \mathrm{I}_{3}$ molecules are organised into columns running along $a$ with a head-to-tail arrangement within the columns. Halogen bonding interactions develop into layers perpendicular to $a$, with halogenbonded chains of alternating sym- $\mathrm{C}_{6} \mathrm{~F}_{3} \mathrm{I}_{3}$ and $\mathrm{SCN}^{-}$running along $c$ (Fig. 3). Their structural characteristics collected in Table 2 are comparable to those observed in $\mathbf{3 b}$. Note also that one iodine atom of the sym- $\mathrm{C}_{6} \mathrm{~F}_{3} \mathrm{I}_{3}$ molecule is not engaged in any halogen bond, but rather acts as an acceptor in a short $\mathrm{I} \cdots$ $\mathrm{H}-\mathrm{C}$ hydrogen bond involving a methylene group of the $\mathrm{Et}_{4} \mathrm{~N}^{+}$ cation, with the following characteristics: I $\cdots \mathrm{H}: 2.095 \AA$; $\mathrm{I} \cdots$ $\mathrm{H}-\mathrm{C}: 147.6^{\circ} ; \mathrm{C}-\mathrm{I} \cdots \mathrm{H}: 128.5^{\circ}$. Note this acute value for the $\mathrm{C}-\mathrm{I} \cdots$ $\mathrm{H}$ angle, which contrasts strongly with the linear $\mathrm{C}-\mathrm{I} \cdots(\mathrm{S}, \mathrm{N})$ interaction. Indeed, in the hydrogen bond interaction, the iodine atom acts as a nucleophile through its lone pairs delocalised in an

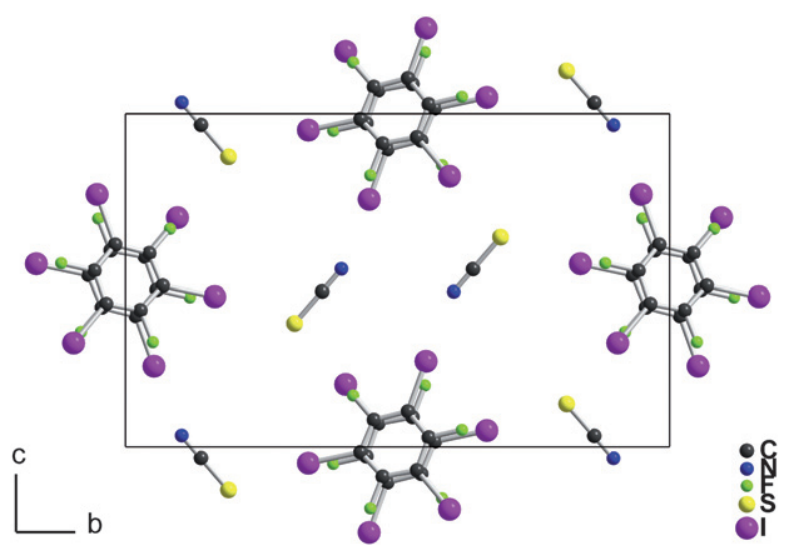

Fig. 2 Projection view of the unit cell of $\mathbf{4 a}$ along $a$. $\mathrm{The} \mathrm{Et}_{4} \mathrm{~N}^{+}$cations have been omitted for clarity.

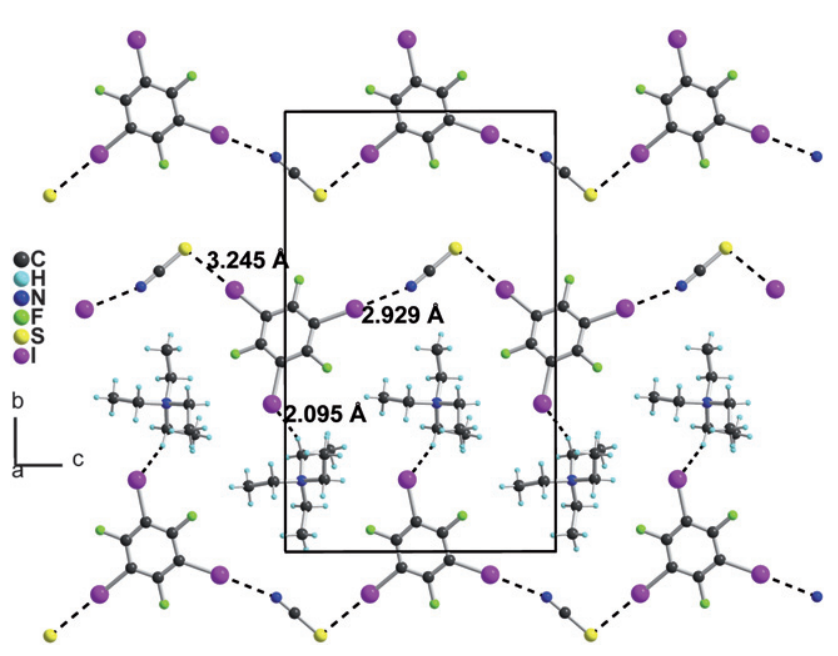

Fig. 3 Projection view along $a$ of one layer in $\mathbf{4 a}$ showing around sym- $\mathrm{C}_{6} \mathrm{~F}_{3} \mathrm{I}_{3}$, the halogen bonds with the $\mathrm{SCN}^{-}$anion and the $\mathrm{I} \cdots \mathrm{H}-\mathrm{C}$ hydrogen bond with the $\mathrm{Et}_{4} \mathrm{~N}^{+}$cation.

equatorial region around the $\mathrm{C}-\mathrm{I}$ bond while in the halogen bond interaction, it acts as the electrophile through the so-called $\sigma$ hole in the extension of the $\mathrm{C}-\mathrm{I}$ bond.

Table 2 Intermolecular contact distances (in $\AA$ ) and angles (in ${ }^{\circ}$ ). For comparison, the calculated non-isotropic contact distances (see text) are $3.36 \AA$ for the $\mathrm{I} \cdots \mathrm{N}$ and $3.79 \AA$ for the $\mathrm{I} \cdots \mathrm{S}$ interactions

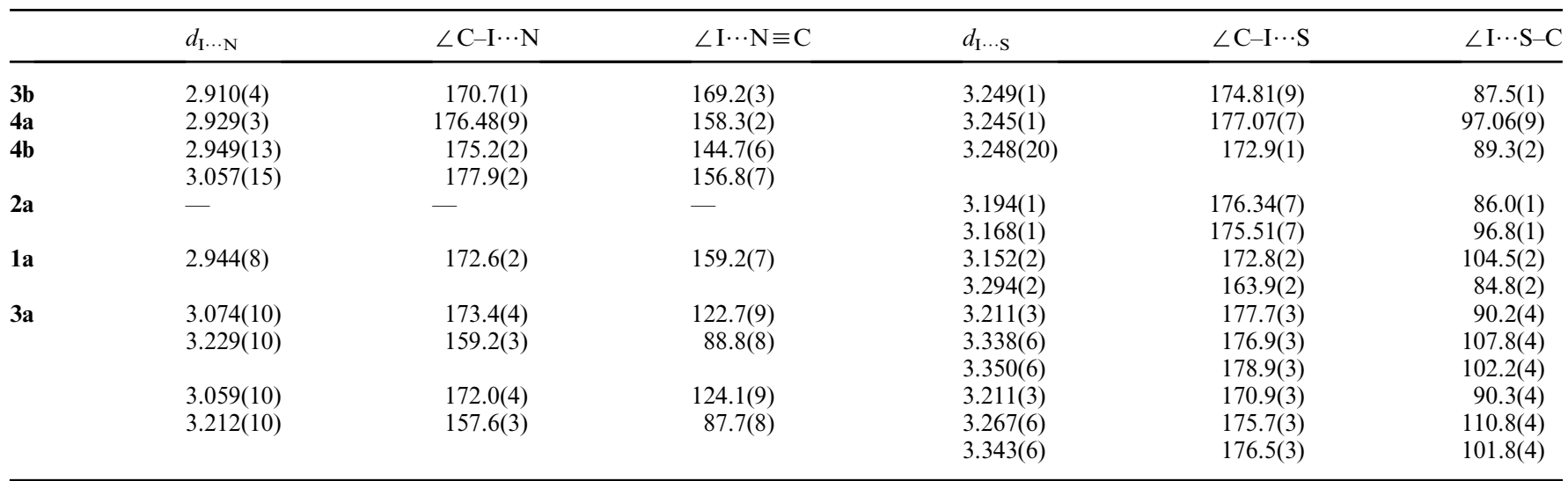




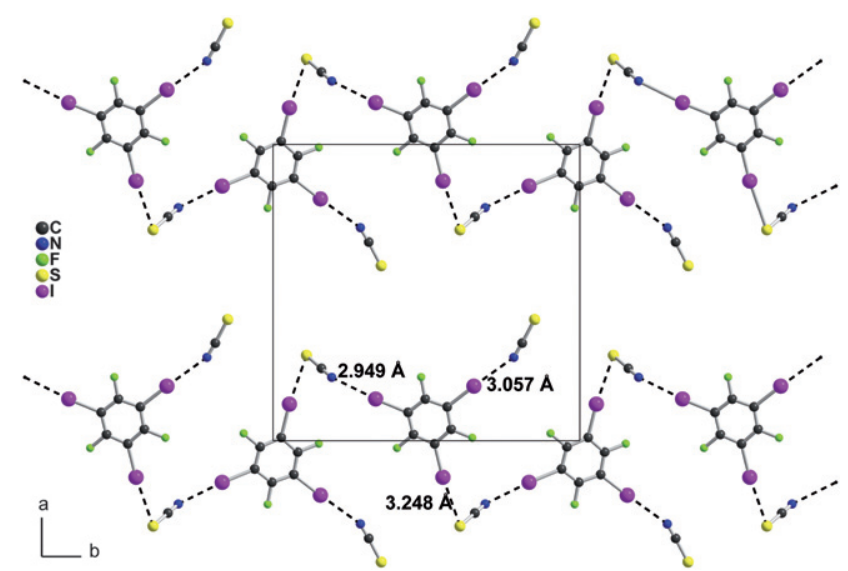

Fig. 4 Projection view of the unit cell of $\mathbf{4 b}$ showing the halogen-bonded chains running along $b$. The $n-\mathrm{Bu}_{4} \mathrm{~N}^{+}$cation has been omitted for clarity.

The corresponding tetrabutylammonium salt $\mathbf{4 b}$ is found to crystallise with a different stoichiometry, that is $\left(n-\mathrm{Bu}_{4} \mathrm{NSCN}\right)_{2}\left(\right.$ sym- $\left.\mathrm{C}_{6} \mathrm{~F}_{3} \mathrm{I}_{3}\right)$ with two thiocyanate salts for one single sym- $\mathrm{C}_{6} \mathrm{~F}_{3} \mathrm{I}_{3}$ molecule. As a consequence of this stoichiometry, we are now in the situation of three iodine atoms as halogen bond donors combined with potentially four halogen bond acceptor atoms $(2 \times \mathrm{S}+2 \times \mathrm{N})$. As shown in Fig. 4, the three iodine atoms of the sym- $\mathrm{C}_{6} \mathrm{~F}_{3} \mathrm{I}_{3}$ molecule are now engaged in halogen bonds, two of them with one $\mathrm{SCN}^{-}$anion to form chains running along $b$ while the third iodine atom is linked to the nitrogen atom of the second $\mathrm{SCN}^{-}$anion, through a slightly longer $\mathrm{I} \cdots \mathrm{N}$ distance.

\section{The thiocyanate anion as a polydentate anion in $\mathbf{2 a}, \mathbf{1 a}$ and $3 \mathrm{a}$}

More complex structures are found with the three $\mathrm{Et}_{4} \mathrm{NSCN}$ salts isolated with the $o$-, $m$ - and $p-\mathrm{C}_{6} \mathrm{~F}_{4} \mathrm{I}_{2}$ molecules. Despite a $1: 1$ stoichiometry, 2a, formulated as $\left(\mathrm{Et}_{4} \mathrm{NSCN}\right)\left(m-\mathrm{C}_{6} \mathrm{~F}_{4} \mathrm{I}_{2}\right)$, does not exhibit the chain motif encountered above with $\mathrm{I} \cdots \mathrm{N}$ and $\mathrm{I} \cdots$ $\mathrm{S}$ interactions but rather two I $\cdots \mathrm{S}$ interactions while the nitrogen atom of the thiocyanate anion does not act as halogen bond acceptor. 2a crystallises in the monoclinic system, space group $C 2 / c$ with one $\mathrm{SCN}^{-}$anion and $m-\mathrm{C}_{6} \mathrm{~F}_{4} \mathrm{I}_{2}$ molecule in general position while two crystallographically independent $\mathrm{Et}_{4} \mathrm{~N}^{+}$ cations are found, both located on the two-fold axis, with one of the two further disordered on two positions. The $m-\mathrm{C}_{6} \mathrm{~F}_{4} \mathrm{I}_{2}$ molecules are organised into parallel (lllll $\left.\begin{array}{lll}1 & 0 & 1\end{array}\right)$ layers. As shown in Fig. 5, within a $\left(\begin{array}{lll}1 & 0 & 1\end{array}\right)$ layer, the thiocyanate anion is halogen bonded to the $m-\mathrm{C}_{6} \mathrm{~F}_{4} \mathrm{I}_{2}$ molecule through two I $\cdots \mathrm{S}$ interactions while the nitrogen atom does not take part into halogen bonding, indicating that it might not be such a strong halogen bond acceptor in comparison with the sulfur atom in the $\mathrm{SCN}^{-}$anion, a feature already observed once by Kochi in the $n \mathrm{Bu}_{4} \mathrm{NSCN}$ salt with $\mathrm{CBr}_{4} \cdot{ }^{29}$

The complex 1a crystallises in the orthorhombic system, space group $\mathrm{Pbca}$ and involves two $\mathrm{o}-\mathrm{C}_{6} \mathrm{~F}_{4} \mathrm{I}_{2}$ molecules in general position for one $\mathrm{Et}_{4} \mathrm{NSCN}$, also in general position in the unit cell. The $o-\mathrm{C}_{6} \mathrm{~F}_{4} \mathrm{I}_{2}$ molecules are organised into columns running along $a$ composed alternately of the two crystallographically independent molecules (Fig. 6). These columns are linked together in the $b$ direction (Fig. 7) through three halogen bond

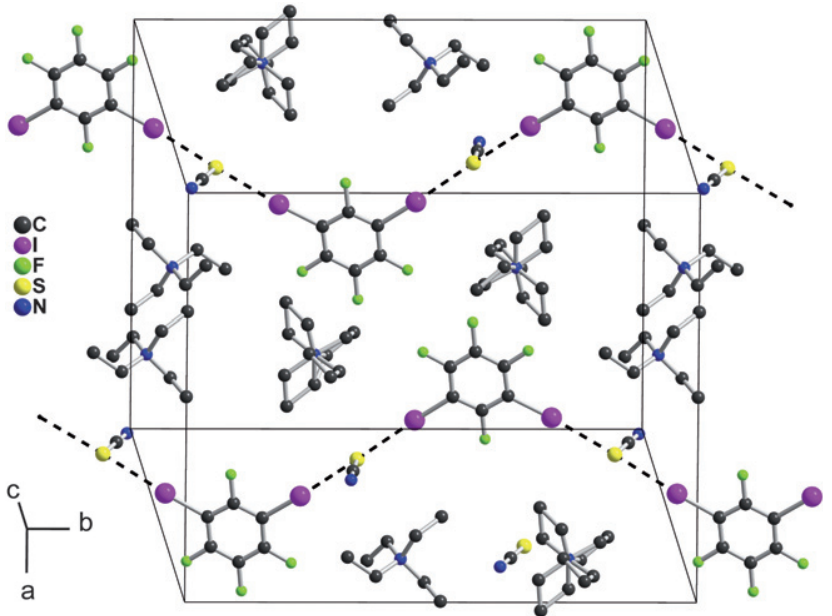

Fig. 5 A view of one (1 $\left.\begin{array}{lll}0 & 1\end{array}\right)$ layer in $\mathbf{2 a}$ showing the thiocyanate anions pointing out of the plane. Hydrogen atoms have been omitted for clarity.

interactions involving the nitrogen and twice the sulfur atom of the $\mathrm{SCN}^{-}$anion.

Finally, the most complex salt obtained with $p-\mathrm{C}_{6} \mathrm{~F}_{4} \mathrm{I}_{2}, \mathbf{3 a}$, crystallises in the monoclinic system, space group $P 2 / a$ and is formulated as $\left(\mathrm{Et}_{4} \mathrm{NSCN}\right)_{2}\left(p-\mathrm{C}_{6} \mathrm{~F}_{4} \mathrm{I}_{2}\right)_{5}$, that is, with five $p-\mathrm{C}_{6} \mathrm{~F}_{4} \mathrm{I}_{2}$ molecules for two $\mathrm{Et}_{4} \mathrm{NSCN}$ salts. Furthermore, two $p-\mathrm{C}_{6} \mathrm{~F}_{4} \mathrm{I}_{2}$ molecules are in general position while six others are located on inversion centres or two-fold axes. A projection view of this complex structure along $b$ (Fig. 8) shows a segregation of the neutral and charged moieties similar to that observed in 1a (Fig. 6). Each of the two $\mathrm{SCN}^{-}$anions is halogen bonded to five different $p-\mathrm{C}_{6} \mathrm{~F}_{4} \mathrm{I}_{2}$ molecules (Fig. 9), three on the sulfur atom and for the first time two on the nitrogen atom, with the shortest $\mathrm{N} \cdots \mathrm{I}$ distance associated with the largest $\mathrm{C}-\mathrm{I} \cdots \mathrm{N}$ angle (Table 2). This unexpected structure around the nitrogen atom can be explained in a crude manner as the contribution of the mesomeric form $\mathrm{C}$, shown in Scheme 3.

In the six structures described above, we observe that the thiocyanate anion adopts specific halogen bond motifs

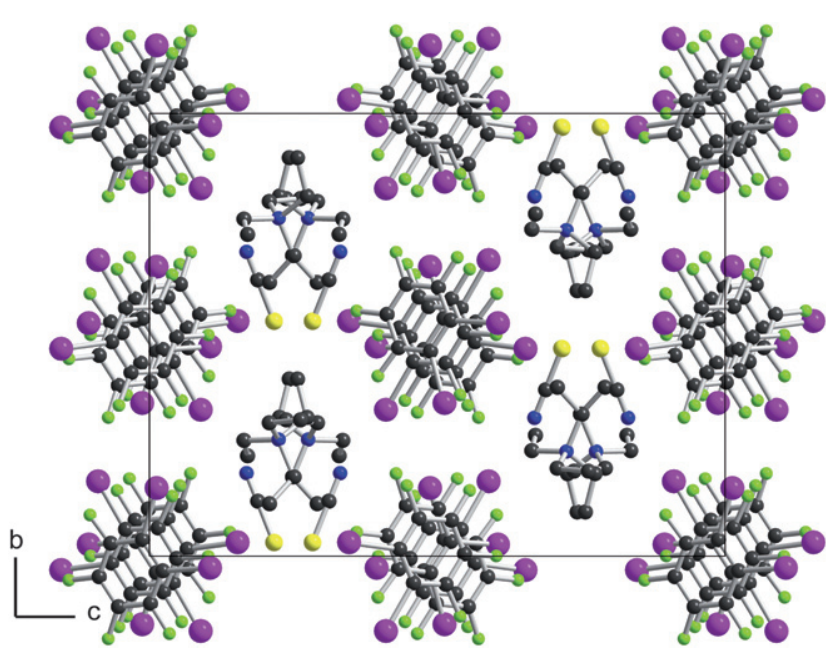

Fig. 6 Projection view along $a$ of the unit cell of 1a, $\left(\mathrm{Et}_{4} \mathrm{NSC}-\right.$ $\mathrm{N})\left(o-\mathrm{C}_{6} \mathrm{~F}_{4} \mathrm{I}_{2}\right)_{2}$. Hydrogen atoms have been omitted for clarity. 


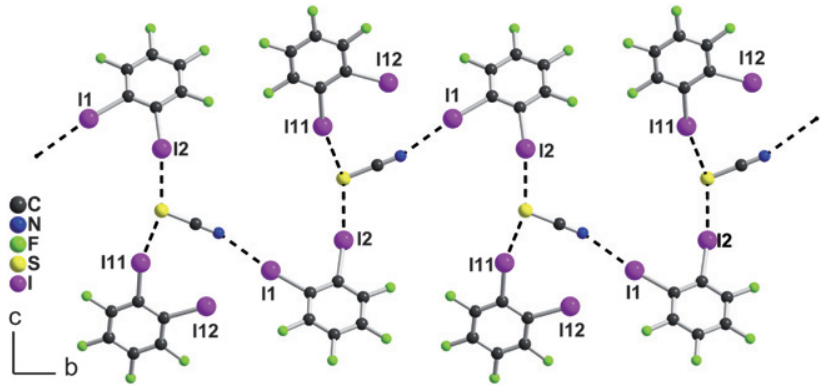

Fig. 7 Halogen bond chain motif running along $b$ in $\mathbf{1 a},\left(\mathrm{Et}_{4} \mathrm{NSCN}\right)-$ $\left(o-\mathrm{C}_{6} \mathrm{~F}_{4} \mathrm{I}_{2}\right)_{2}$.

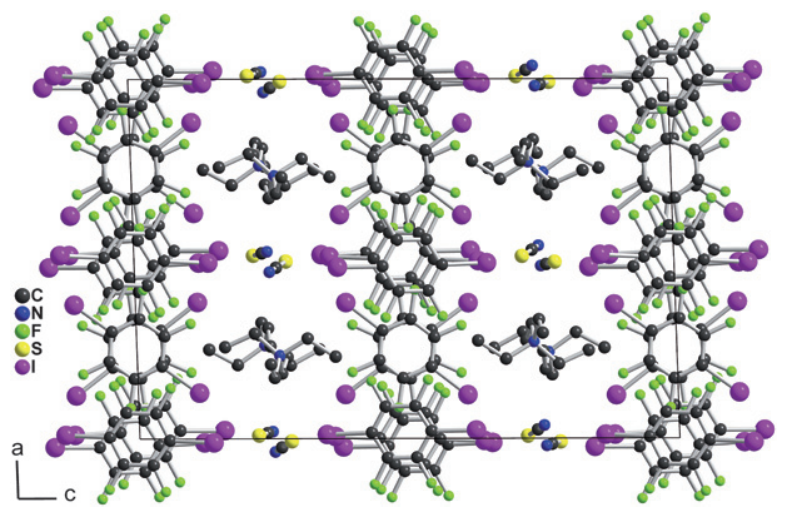

Fig. 8 Projection view along $b$ of the unit cell of 3a. Hydrogen atoms have been omitted for clarity.

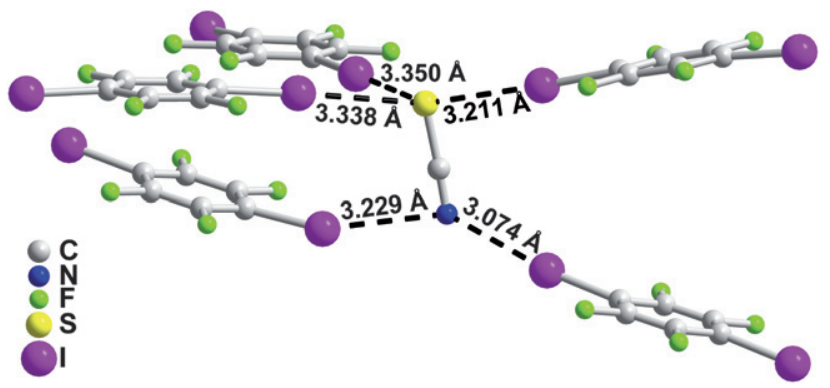

Fig. 9 Detail of the halogen bond network around one of the two crystallographically independent $\mathrm{SCN}^{-}$anions in $\mathbf{3 a}$.

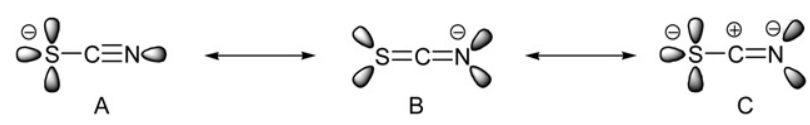

Scheme 3 Lewis description of three mesomeric forms of the $\mathrm{SCN}^{-}$ anion. The grey ellipsoids represent the lone pairs around the $\mathrm{S}$ and $\mathrm{N}$ atoms.

characterized by systematic linear $\mathrm{C}-\mathrm{I} \cdots(\mathrm{N}, \mathrm{S})$ contacts, in agreement with earlier results showing the alignment of the electron depletion zone in the extension of the C-I bond. The geometrical features observed by Bock and Holl, ${ }^{26-28}$ and $\mathrm{Kochi}^{29}$ in their earlier work are confirmed, that is a linear $\mathrm{C}-\mathrm{I} \cdots(\mathrm{N}, \mathrm{S})$ contact while the $\mathrm{I} \cdots \mathrm{N} \equiv \mathrm{C}$ angle deviates notably from linearity $\left(145-170^{\circ}\right)$ and acute $\mathrm{I} \cdots \mathrm{S}-\mathrm{C}$ angles $\left(<90^{\circ}\right)$ are systematically observed. Furthermore, examples were found where the sulfur atom is "coordinated" two times (in 2a) or even three times (in 3a) simultaneously, showing that formally, the three lone pairs on the $\mathrm{S}$ atom in the Lewis description of the $\mathrm{SCN}^{-}$anion can act as halogen bond acceptors. On the other hand, we note here two examples where the nitrogen atom behaves in an unexpected way, either by staying free of any halogen bond (in 2a) or by linking simultaneously to two different iodine atoms at the same time (in 3a). It therefore appears that the two $\mathrm{N}$ and $\mathrm{S}$ atoms in the $\mathrm{SCN}^{-}$ anion most probably exhibit a very comparable tendency to engage into halogen bonds. Theoretical calculations were performed to rationalise these experimental solid state observations, as detailed below. In order to allow comparisons with our earlier results concerning the halogen bonding of halide anions $\left(\mathrm{Cl}^{-}, \mathrm{Br}^{-}\right)$ with the sym-trifluorotriiodobenzene, ${ }^{18}$ the calculations were similarly performed here for the same sym- $\mathrm{C}_{6} \mathrm{~F}_{3} \mathrm{I}_{3}$ molecule, interacting through one iodine atom with either the $\mathrm{N}$ or $\mathrm{S}$ end of the $\mathrm{SCN}^{-}$anion.

\section{Theoretical study of the $s y m-\mathrm{C}_{6} \mathrm{~F}_{3} \mathrm{I}_{3} \cdots \mathrm{NCS}^{-}$complex}

The energetic values, geometrical optimizations and frequency calculations of sym- $\mathrm{C}_{6} \mathrm{~F}_{3} \mathrm{I}_{3}$ and $\mathrm{NCS}^{-}$in both coordination modes $(\mathrm{C}-\mathrm{I} \cdots \mathrm{N}$ or $\mathrm{C}-\mathrm{I} \cdots \mathrm{S})$ have been calculated using DFT methods. One complex is found for each coordination mode. Interestingly, both complexation energies are very similar, -16.97 and $-16.43 \mathrm{kcal} / \mathrm{mol}$ for $\mathrm{C}-\mathrm{I} \cdots \mathrm{N}$ and $\mathrm{C}-\mathrm{I} \cdots \mathrm{S}$, respectively, although the equilibrium geometrical parameters are substantially different. Hence, coordination through the $\mathrm{N}$ atom yields an $\mathrm{I} \cdots \mathrm{N}$ equilibrium distance of $2.599 \AA$ and an angle $\mathrm{I} \cdots$ $\mathrm{N} \equiv \mathrm{C}$ of $151.3^{\circ}$ while the complex formed through the $\mathrm{S}$ atom presents an $\mathrm{I} \cdots \mathrm{S}$ equilibrium distance of $3.007 \AA$ and an angle $\mathrm{I} \cdots$ $\mathrm{S}-\mathrm{C}$ of $103.2^{\circ}$ (Fig. 10). In both cases, the $\mathrm{C}-\mathrm{I} \cdots \mathrm{X}(\mathrm{X}=\mathrm{N}, \mathrm{S})$ angles present a linear rearrangement. The calculations are carried out in a gas-phase environment and, therefore, the charge transfer process is overestimated, leading to calculated $\mathrm{I} \cdots(\mathrm{S}, \mathrm{N})$ distances notably shorter than the experimentally observed ones. This trend has already been observed in the calculated interaction with halide anions where counterions or simultaneous participation into two, three, four or five halogen bonds should be taken into account in order to get comparable results.

Further insight into the geometrical differences between both interaction modes can be gained considering the variation of the complexation energy with regard to $\mathrm{I} \cdots \mathrm{X}$ distance, from 2.3 to $3.3 \AA$, and $\mathrm{C}-\mathrm{I} \cdots \mathrm{X}$ angles, from 90 to $180^{\circ}$ (Fig. 11). The $\mathrm{C}-\mathrm{I} \cdots \mathrm{N}$ interaction mode presents a relatively flat minimum surface for $r(\mathrm{I} \cdots \mathrm{N})$ between 2.5 and $2.8 \AA$ and for $\alpha(\mathrm{I} \cdots \mathrm{N} \equiv \mathrm{C})$ between 130 and $180^{\circ}$ whereas the minimum in the $\mathrm{C}-\mathrm{I} \cdots \mathrm{S}$ interaction is found for $r(\mathrm{I} \cdots \mathrm{S})$ distances between 2.9 and $3.2 \AA$ and a $\alpha(\mathrm{I} \cdots$ S-C) angle between 90 and $110^{\circ}$.

A topological characterization of weak interactions, such as hydrogen bonds can be obtained using the theory of Atoms-inMolecules $^{36}$ (AIM) and the analysis of the ELF. Hence, both halogen bonding modes are characterized by the presence of a $(3,-1)$ bond critical point (bcp) on the topology of the electronic density with similar values of the density $(0.037,0.031$ in a.u.) and Laplacian $(0.093,0.047)$ for $\mathrm{C}-\mathrm{I} \cdots \mathrm{N}$ and $\mathrm{C}-\mathrm{I} \cdots \mathrm{S}$ interactions at the respective bcp coordinates. The topological partition 

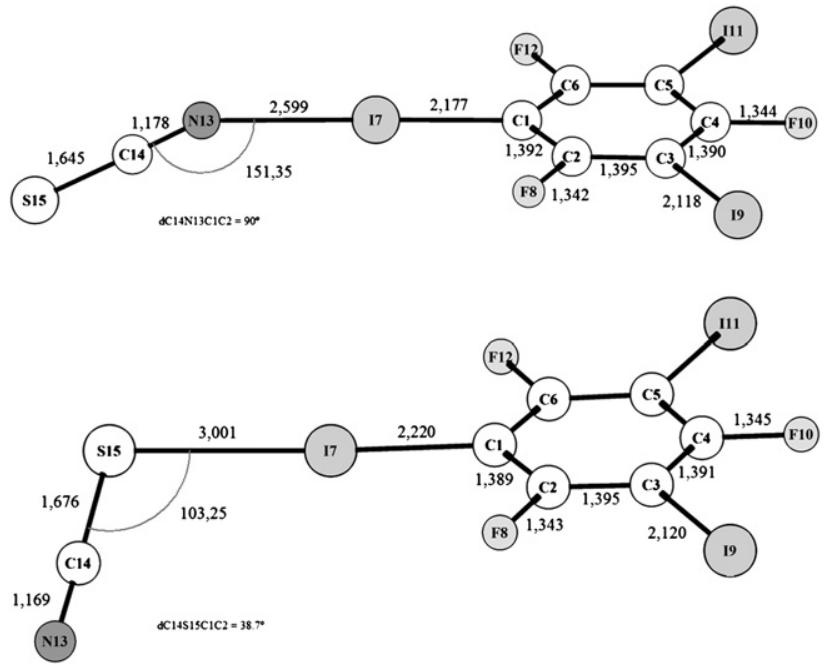

Fig. 10 DFT optimized geometrical parameters for interaction of sym$\mathrm{C}_{6} \mathrm{~F}_{3} \mathrm{I}_{3}$ with $\mathrm{SCN}^{-}$, through the $\mathrm{I} \cdots \mathrm{N}$ (top) or $\mathrm{I} \cdots \mathrm{S}$ interaction (bottom).
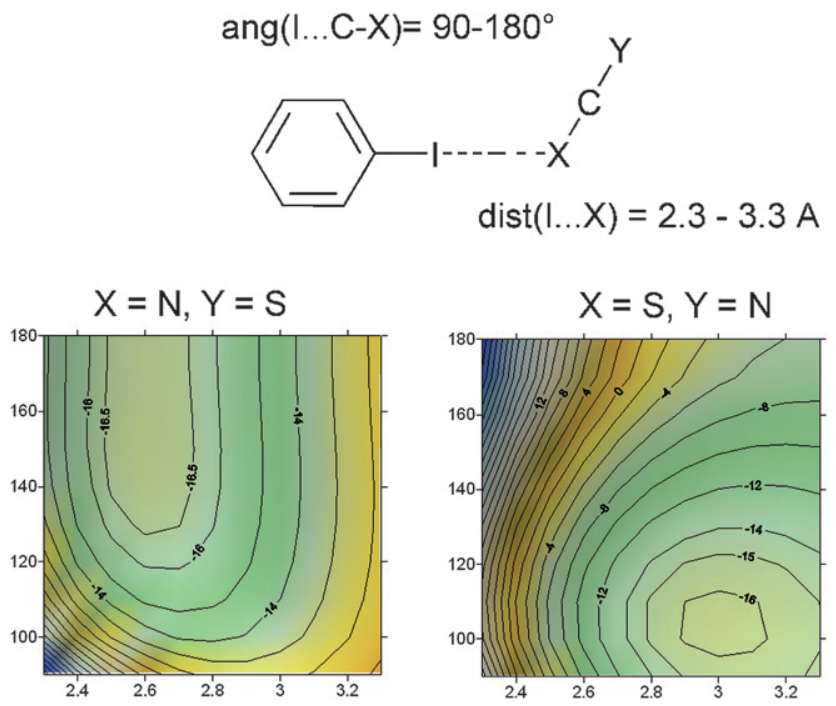

Fig. 11 Complexation energy maps calculated at DFT level for I $\cdots X$ distances (on the abscissa) and $\mathrm{I} \cdots \mathrm{X}-\mathrm{C}$ angles (on the ordinate) for the $\mathrm{I} \cdots \mathrm{N}$ (left) and $\mathrm{I} \cdots \mathrm{S}$ (right) coordination modes.

of the ELF gradient field yields basins of attractors that can be identified as corresponding to atomic cores (C) and valence electrons (V). According to the number of core basins in contact (the synaptic order), valence basins can be characterized as monosynaptic, disynaptic etc. Monosynaptic basins, labeled $\mathrm{V}(\mathrm{A})$ correspond to lone pairs while disynaptic basins, labeled $\mathrm{V}(\mathrm{A}, \mathrm{B})$ are associated to the bonding region between atoms $\mathrm{A}$ and B. Bifurcation points between ELF valence basins of different monomers have been proposed in order to characterize hydrogen bonding interactions. ${ }^{37}$ For the halogen bonds considered in this work the bifurcation points of $\mathrm{C}-\mathrm{I} \cdots \mathrm{N}$ and $\mathrm{C}-\mathrm{I} \cdots \mathrm{S}$ complexation modes corresponding to $\mathrm{V}(\mathrm{I}) \cup \mathrm{V}(\mathrm{N})$ and $\mathrm{V}(\mathrm{I}) \cup \mathrm{V}(\mathrm{S})$ connections have values of $\eta(r)=0.187$ and $\eta(r)=0.270$, respectively. These values are similar to hydrogen bonds of medium strength.
Further insight can be obtained by analyzing the two electronic factors playing a key role for the $\mathrm{C}-\mathrm{I} \cdots \mathrm{N}, \mathrm{S}$ interactions: (i) charge transfer from the anion to the $\mathrm{C}_{6} \mathrm{~F}_{3} \mathrm{I}_{3}$ molecule and (ii) shape and orientation of the $\mathrm{N}$ and $\mathrm{S}$ lone pairs. The amount of charge transferred can be estimated theoretically using different approaches. Natural bond orbital (NBO) analysis on both complexes gives a transfer from $\mathrm{NCS}^{-}$to $\mathrm{C}_{6} \mathrm{~F}_{3} \mathrm{I}_{3}$ of $0.13 \mathrm{e}$ and 0.26 e for $\mathrm{C}-\mathrm{I} \cdots \mathrm{N}$ and $\mathrm{C}-\mathrm{I} \cdots \mathrm{S}$ complexes, respectively. Other methodologies to calculate the charge transfer are based on topological approaches and yield very similar values: $0.14 \mathrm{e}$ and $0.27 \mathrm{e}$ using the AIM theory (based on the electron density) and $0.12 \mathrm{e}$ and $0.21 \mathrm{e}$ using the ELF for $\mathrm{C}-\mathrm{I} \cdots \mathrm{N}$ and $\mathrm{C}-\mathrm{I} \cdots \mathrm{S}$ complexes, respectively. Hence, the smaller electronegativity of $\mathrm{S}$ compared to $\mathrm{N}$ allows for a more efficient charge transfer to the halogen bond donor and leads to a larger stabilization of the complex. The second factor can be best analyzed by means of the ELF, which localises electron pairs within the geometrical space and integrates the amount of electron density of each electron pair providing an understanding of the different geometric structures. The ELF analysis of isolated $\mathrm{NCS}^{-}$shows one monosynaptic valence basin for $\mathrm{N}$ and $\mathrm{S}$ containing $3.83 \mathrm{e}$ and $5.79 \mathrm{e}$, respectively (see Fig. 12). This electron population can be interpreted as a superposition of mesomeric structures B and $\mathrm{C}$ described previously (Scheme 3). Inspection of the shape of $\mathrm{V}(\mathrm{N})$ and $\mathrm{V}(\mathrm{S})$ basins reveals clear differences between both

(a)
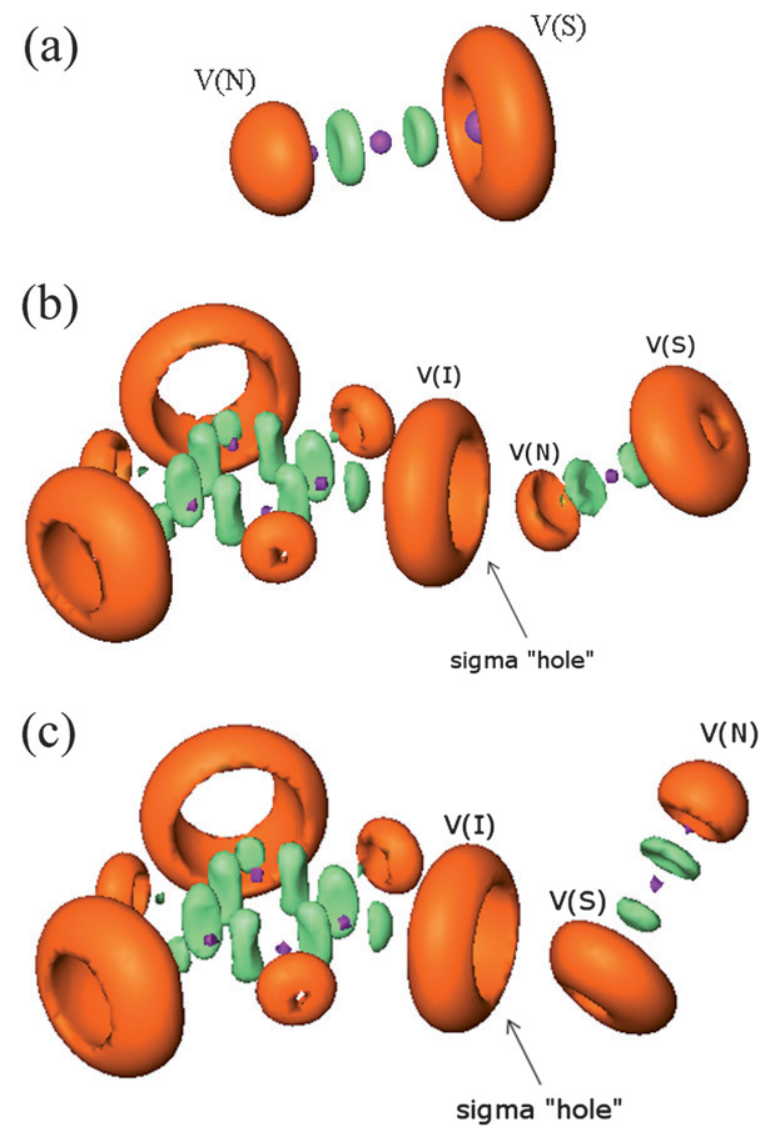

Fig. 12 ELF plot (isocontour value of 0.80) for $\mathrm{NCS}^{-}$(a), $\mathrm{C}_{6} \mathrm{~F}_{3} \mathrm{I}_{3} \cdots$ $\mathrm{NCS}^{-}$(b) and $\mathrm{C}_{6} \mathrm{~F}_{3} \mathrm{I}_{3} \cdots \mathrm{S}-\mathrm{CN}^{-}$(c). Core basins in purple, monosynaptic basins in orange and disynaptic basins in green. 

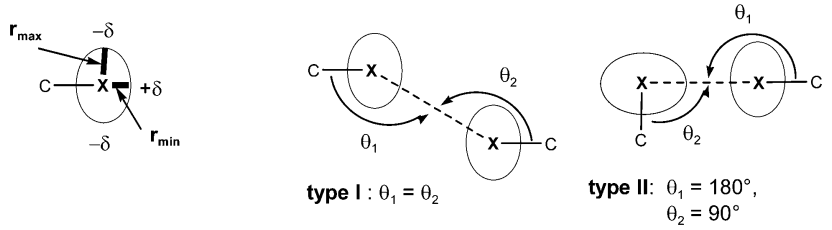

Scheme 4 Anisotropic electronic distribution around the halogen (X) atom and geometric features of type I and type II motifs.

terminal lone pairs. While $\mathrm{V}(\mathrm{N})$ is compact and lying on the molecular axis, $\mathrm{V}(\mathrm{S})$ is much more voluminous and adopts a nearly toroidal shape around the core electrons of $\mathrm{S}$. As it can be observed in Fig. 12, the interaction between $\mathrm{C}_{6} \mathrm{~F}_{3} \mathrm{I}_{3}$ and $\mathrm{NCS}^{-}$takes place between the lone pairs $\mathrm{V}(\mathrm{N})$ and $\mathrm{V}(\mathrm{S})$ for the $\mathrm{N}$ or $\mathrm{S}$ coordination modes, respectively, and the halogen bond donor through the sigma "hole" located in the prolongation of the $\mathrm{C}-\mathrm{I}$ bond. The more compact nature of $\mathrm{V}(\mathrm{N})$ allows a closer approach to the I nucleus in a nearly linear way while the shape of V(S) enforces a much longer I...S distance and a nearly $90^{\circ}$ approach to the I nucleus. It should be noted that $\mathrm{V}(\mathrm{S})$ also presents a small sigma "hole" in the back side of the $\mathrm{S}-\mathrm{C}$ bond similar to $\mathrm{V}(\mathrm{I})$ which prevents the linear approach to the halogen bond donor. This interaction pattern is actually closely related to the so-called type II interaction between halogens described by Desiraju (Scheme 4). ${ }^{5}$

Indeed, the sulfur atom plays here the role of the halogen bond acceptor atom in a strong, type II, halogen $\cdots$ halogen interaction. This ability of the sulfur atom of the $\mathrm{SCN}^{-}$anion to interact sideways as a halogen bond acceptor group has been observed only very recently in metal thiocyanate complexes where the $\mathrm{NCS}^{-}$anion is N-bonded to the metal, giving $\mathrm{M}-\mathrm{NCS}$ motifs and leaving the sulfur atom at the periphery available for interaction with halogen bond donors. Indeed, salts of cationic diiodotetrathiafulvalenes with either isolated $\left[\mathrm{Cr}(\text { isoq })_{2}(\mathrm{NCS})_{4}\right]^{-, 38}$ or polymeric $\left[\mathrm{Cd}_{3}(\mathrm{NCS})_{8}\right]^{2-}$ moieties $^{39}$ exhibit short $\mathrm{I} \cdots \mathrm{S}$ contact with $\mathrm{C}-\mathrm{I} \cdot \mathrm{NS}$ angles essentially linear while the $\mathrm{I} \cdots \mathrm{S}-\mathrm{C}$ angles are systematically around $90^{\circ}$.

\section{Conclusions}

In the examples reported earlier, ${ }^{26-29}$ the halogen bond donor molecules reported had each four iodine (Scheme 1) or bromine $\left(\mathrm{CBr}_{4}\right)$ atoms available for halogen bonding to the $\mathrm{SCN}^{-}$anion, affording structures where the thiocyanate anion was systematically linked to at least three to five iodine atoms. Using here benzene derivatives with only two or three activated iodine atoms, we were able to enhance the selectivity of the halogen interaction, and to discriminate more precisely the respective ability of the sulfur and nitrogen atom to engage in such halogen bond interactions. The analysis of the six structures described here combined with the theoretical calculations clearly shows the ambivalent character of the $\mathrm{SCN}^{-}$anion and demonstrates the ability of the sulfur and nitrogen ends to interact with halogen bond donors with comparable strength. This ambivalent character of the $\mathrm{SCN}^{-}$anion towards halogen bonding is strongly reminiscent of its similar behaviour toward metal coordination, particularly with group $12(\mathrm{Zn}, \mathrm{Cd}, \mathrm{Hg}) \mathrm{d}^{10}$ metal cations, which are best understood in terms of the hard-soft acid-base concept developed by Pearson, Basolo and Burmeister. ${ }^{40}$ Indeed, while the $\mathrm{Zn}$ tetrahedral thiocyanate complexes tend to be N-bonded, the tetrahedral $\mathrm{Hg}$ complexes are almost always S-bonded. The $\mathrm{Cd}^{2+}$ cation in between becomes "schizophrenic", ${ }^{41}$ exhibiting both $\mathrm{S}$ and $\mathrm{N}$ bonding modes and a variety of coordination numbers, exactly as observed here when faced with halogen bond donor molecules such as the iodo aromatics collected in Schemes 1 and 2 .

Table 3 Crystallographic data

\begin{tabular}{|c|c|c|c|c|c|c|}
\hline & 1a & $\mathbf{2 a}$ & $3 \mathbf{a}$ & $3 \mathbf{b}$ & $4 \mathbf{a}$ & $4 b$ \\
\hline Formula & $\mathrm{C}_{21} \mathrm{H}_{20} \mathrm{~F}_{8} \mathrm{I}_{4} \mathrm{~N}_{2} \mathrm{~S}$ & $\mathrm{C}_{15} \mathrm{H}_{20} \mathrm{~F}_{4} \mathrm{I}_{2} \mathrm{~N}_{2} \mathrm{~S}$ & $\mathrm{C}_{48} \mathrm{H}_{40} \mathrm{~F}_{20} \mathrm{I}_{10} \mathrm{~N}_{4} \mathrm{~S}_{2}$ & $\mathrm{C}_{23} \mathrm{H}_{36} \mathrm{~F}_{4} \mathrm{I}_{2} \mathrm{~N}_{2} \mathrm{~S}$ & $\mathrm{C}_{15} \mathrm{H}_{20} \mathrm{~F}_{3} \mathrm{I}_{3} \mathrm{~N}_{2} \mathrm{~S}$ & $\mathrm{C}_{40} \mathrm{H}_{72} \mathrm{~F}_{3} \mathrm{I}_{3} \mathrm{~N}_{4} \mathrm{~S}_{2}$ \\
\hline FW & 992.05 & 590.19 & 2385.96 & 702.40 & 698.09 & 1110.84 \\
\hline Cryst syst & Orthorhombic & Monoclinic & Monoclinic & Monoclinic & Monoclinic & Monoclinic \\
\hline Space group & Pbca & $C 2 / c$ & $P 2 / a$ & $P 2_{1} / n$ & $P 2_{1} / n$ & $P 2_{1} / c$ \\
\hline$a / \AA$ & $15.809(7)$ & $17.7404(8)$ & $16.4673(12)$ & $10.0837(7)$ & $8.0510(4)$ & $17.574(4)$ \\
\hline$b / \AA$ & $16.566(8)$ & $22.8074(10)$ & $16.4260(14)$ & $22.4174(14)$ & $21.1985(12)$ & $18.064(4)$ \\
\hline$c / \AA$ & $21.461(8)$ & $12.1785(6)$ & $24.711(2)$ & $12.9033(8)$ & $13.2534(5)$ & $16.310(3)$ \\
\hline$\alpha /^{\circ}$ & 90.0 & 90.0 & 90.0 & 90.0 & 90.0 & 90.0 \\
\hline$\beta /^{\circ}$ & 90.0 & $126.259(1)$ & $91.847(3)$ & $93.2206(19)$ & $100.872(2)$ & $97.42(3)$ \\
\hline$\gamma /^{\circ}$ & 90.0 & 90.0 & 90.0 & 90.0 & 90.0 & 90.0 \\
\hline$V / \AA^{3}$ & $5621(4)$ & $3973.4(3)$ & $6680.7(9)$ & $2912.2(3)$ & $2221.35(19)$ & $5134.1(18)$ \\
\hline$Z$ & 8 & 8 & 4 & 4 & 4 & 4 \\
\hline$d_{\text {calc }} / \mathrm{Mg} \mathrm{m}^{-3}$ & 2.345 & 1.973 & 2.372 & 1.602 & 2.087 & 1.437 \\
\hline $\mathrm{Temp} / \mathrm{K}$ & 100 & 100 & 100 & 293 & 100 & 293 \\
\hline$\mu / \mathrm{mm}^{-1}$ & 4.577 & 3.306 & 4.793 & 2.270 & 4.340 & 1.947 \\
\hline$\theta$-range $/^{\circ}$ & $3.43-27.48$ & $3.57-27.47$ & $3.44-27.48$ & $2.41-27.57$ & $3.40-27.42$ & $2.91-27.48$ \\
\hline Meas. refls & 18884 & 17224 & 67743 & 61852 & 20203 & 98554 \\
\hline Indep. refls & 6355 & 4356 & 14927 & 6715 & 5003 & 11735 \\
\hline$R_{\text {int }}$ & 0.0741 & 0.0379 & 0.0466 & 0.0423 & 0.0307 & 0.0956 \\
\hline$I>2 \sigma(I)$ refls & 4621 & 4083 & 12218 & 4588 & 4431 & 8057 \\
\hline Abs. corr. & multi-scan & multi-scan & multi-scan & multi-scan & multi-scan & multi-scan \\
\hline$T_{\max }, T_{\min }$ & $0.104,0.795$ & $0.245,0.396$ & $0.140,0.443$ & $0.7200,1.0$ & $0.146,0.545$ & $0.5782,1.2086$ \\
\hline refined par. & 329 & 238 & 757 & 309 & 221 & 469 \\
\hline$R(F), I>2 \sigma(I)$ & 0.0518 & 0.0216 & 0.0629 & 0.0317 & 0.0203 & 0.0457 \\
\hline$w R\left(F^{2}\right)$, all & 0.1418 & 0.0544 & 0.1542 & 0.0738 & 0.0407 & 0.1374 \\
\hline$\Delta \rho / e \AA^{-3}$ & $-2.35,1.63$ & $-0.66,0.11$ & $-1.63,3.59$ & $-0.56,0.81$ & $-0.49,0.64$ & $-0.81,0.76$ \\
\hline
\end{tabular}




\section{Experimental}

The four neutral molecules $o-, m$ - or $p$-diodoperfluorobenzene and the sym-trifluorotriiodobenzene were either commercially available ( $p$ - and $o$-diiodoperfluorobenzene) or prepared according to published procedures ( $m$-diiodoperfluorobenzene, ${ }^{42}$ sym-trifluorotriiodobenzene ${ }^{43}$ ). Crystallisation experiments for the $\mathrm{Et}_{4} \mathrm{NSCN}$ salts 1a-d were performed by mixing equimolar quantities $(0.125 \mathrm{mmol})$ of $\mathrm{Et}_{4} \mathrm{NSCN}$ and the aromatic in $\mathrm{EtOH}$ $\left(3 \mathrm{~mL}\right.$ ). Slow addition of water and cooling to $4{ }^{\circ} \mathrm{C}$ afforded the title compounds as colourless crystals. The $n \mathrm{Bu}_{4} \mathrm{NSCN}$ salts $\mathbf{3 b}$ and $\mathbf{4 b}$ were obtained from slow evaporation of $\mathrm{CH}_{2} \mathrm{Cl}_{2}$ solutions containing $p$-diodoperfluorobenzene $(0.1 \mathrm{~g}, 0.25 \mathrm{mmol})$ or sym-trifluorotriiodobenzene $(0.1 \mathrm{~g}, 0.2 \mathrm{mmol})$ with, respectively, one or two equiv. $n \mathrm{Bu}_{4} \mathrm{SCN}$.

\section{Crystallography}

X-Ray data collections (Table 3) were performed, either on an APEXII, Bruker-AXS diffractometer at 100(2) K for 1a, 2a, 3a and $\mathbf{4 a}$, or on an Enraf-Nonius Kappa-CCD diffractometer at 293(2) $\mathrm{K}$ for $\mathbf{3 b}$ and $\mathbf{4 b}$, both with graphite-monochromated Mo $\mathrm{K} \alpha$ radiation $(\lambda=0.71073 \AA)$. Structures were solved by direct methods (SHELXS-9744 or SIR-97) ${ }^{45}$ and refined by full matrix least-squares methods (SHELXL-97), as implemented in the WinGX software package. ${ }^{46}$ Absorption correction was applied. Hydrogen atoms were introduced at calculated positions (riding model), included in structure factor calculations, and not refined.

\section{Theoretical methods}

All calculations have been carried out by means of the GAUSSIAN03 package. ${ }^{47}$ All DFT calculations were performed at the B3LYP level using the $6-311 \mathrm{G}(\mathrm{d}, \mathrm{p})$ basis set for iodine and $6-311++\mathrm{G}(\mathrm{d}, \mathrm{p})$ basis set for the other atoms. ${ }^{48,49}$ Complexation energies are defined as $\left[E\left(\right.\right.$ sym- $\left.\mathrm{C}_{6} \mathrm{~F}_{3} \mathrm{I}_{3} \cdots \mathrm{SCN}^{-}\right)-E\left(\right.$ sym- $\left.\mathrm{C}_{6} \mathrm{~F}_{3} \mathrm{I}_{3}\right)$ $\left.-\mathrm{E}\left(\mathrm{SCN}^{-}\right)\right]$. The basis set superposition error for the optimized structures of sym- $\mathrm{C}_{6} \mathrm{~F}_{3} \mathrm{I}_{3}$ with $\mathrm{SCN}^{-}$, through the $\mathrm{I} \cdots \mathrm{N}$ or $\mathrm{I} \cdots \mathrm{S}$ interaction is $2.65 \mathrm{kcal} / \mathrm{mol}$ and $0.60 \mathrm{kcal} / \mathrm{mol}$, respectively. No BSSE correction to the complexation energies was applied. Energy maps were carried out at the same level of theory by means of optimizations, fixing the $\mathrm{I} \cdots \mathrm{X}$ distances and $\mathrm{I} \cdots \mathrm{X}-\mathrm{C}$ angles in both coordination modes as indicated in Fig. 11. The AIM and ELF topological analyses have been carried out using the TopMod program developed by Silvi et a $l^{50}$ using a cubic grid with a step size of 0.1. Graphic representations of ELF have been obtained using the Amira software. ${ }^{51}$

\section{Acknowledgements}

This work was supported by the ANR (Paris) under reference ANR-08-BLAN-0091-02, Ministerio de Ciencia e Innovación (Project CTQ2008-02670/BQU), Fundació Bancaixa-Universitat Jaume I (Grant P1.1B2007-12), Generalitat Valenciana (Grant ACOMP/2009/105), and the European COST D35 Action, Working Group 11. The authors are also grateful to the Servei d'Informatica, Universitat Jaume I, Castelló, Spain, for generous allotment of computing time.

\section{References}

1 O. Hassel, Science, 1970, 170, 497.

2 (a) P. Metrangolo, T. Pilati and G. Resnati, CrystEngComm, 2006, 8, 946; (b) Halogen Bonding: Fundamentals and Applications; Struct. Bond, ed. P. Metrangolo and G. Resnati, Springer, Berlin, vol. 126, 2008.

3 P. Metrangolo, H. Neukirch, T. Pilati and G. Resnati, Acc. Chem. Res., 2005, 38, 386.

4 (a) P. Metrangolo and G. Resnati, Chem.-Eur. J., 2001, 7, 2511; (b) E. Corradi, S. V. Meille, M. T. Messina, P. Metrangolo and G. Resnati, Angew. Chem., Int. Ed., 2000, 39, 1782.

5 (a) G. R. Desiraju, Crystal Engineering: The Design of Organic Solids, Elsevier, Amsterdam, 1989, (ch. 6) and references therein; (b) G. R. Desiraju and R. Pathasarathy, J. Am. Chem. Soc., 1989, 111, 8725.

6 (a) J. P. M. Lommerse, A. J. Stone, R. Taylor and F. H. Allen, J. Am. Chem. Soc., 1996, 118, 3108; (b) L. Brammer, E. A. Bruton and P. Sherwood, Cryst. Growth Des., 2001, 1, 277.

7 P. Metrangolo, G. Resnati, T. Pilati and S. Biella, Struct. Bonding, 2008, 126, 105.

8 P. Metrangolo, F. Meyer, T. Pilati, G. Resnati and G. Terraneo, Angew. Chem., Int. Ed., 2008, 47, 6114.

9 P. Metrangolo, T. Pilati, G. Resnati and A. Stevenazzi, Chem. Commun., 2004, 1492.

10 L. Brammer, G. Minguez Espallargas and S. Libri, CrystEngComm, 2008, 10, 1712.

11 The opposite situation has also been addressed: T. Devic, J. N. Bertran, B. Domercq, E. Canadell, N. Avarvari, P. AubanSenzier and M. Fourmigué, New J. Chem., 2001, 25, 1418.

12 (a) L. Brammer, G. Minguez Espallargas and H. Adams, CrystEngComm, 2003, 5, 343; (b) G. Minguez Espallargas, L. Brammer and P. Sherwood, Angew. Chem., Int. Ed., 2006, 45, 435; (c) F. Zordan and L. Brammer, Acta Crystallogr., Sect. B: Struct. Sci., 2004, 60, 512; (d) F. Zordan, S. L. Purver, H. Adams and L. Brammer, CrystEngComm, 2005, 7, 350; (e) F. Zordan, G. Minguez Espallargas and L. Brammer, CrystEngComm, 2006, 8, 425; (f) G. Minguez Espallargas, L. Brammer, D. R. Allan, C. R. Pulham, N. Robertson and J. E. Warren, J. Am. Chem. Soc., 2008, 130, 9058.

13 (a) R. D. Willett, F. Awwadi, R. Butcher, S. Haddad and B. Twamley, Cryst. Growth Des., 2003, 3, 301; (b) F. F. Awwadi, R. D. Willett and B. Twamley, Cryst. Growth Des., 2007, 7, 624; (c) M. Freytag, P. G. Jones, B. Ahrens and A. K. Fischer, New J. Chem., 1999, 23, 1137; (d) M. Freytag and P. G. Jones, Chem. Commun., 2000, 277; (e) T. A. Logothetis, F. Meyer, P. Metrangolo, T. Pilati and G. Resnati, New J. Chem., 2004, 28, 760.

14 T. Imakubo, H. Sawa and R. Kato, Synth. Met., 1995, 73, 117.

15 For reviews, see: (a) M. Fourmigué and P. Batail, Chem. Rev., 2004, 104, 5379; (b) M. Fourmigué, Struct. Bonding, 2008, 126, 181.

16 R. Weiss, M. Rechinger, F. Hampel and A. Wolski, Angew. Chem., Int. Ed. Engl., 1995, 34, 441.

17 (a) M. Ghassemzadeh, K. Harms and K. Dehnicke, Chem. Ber., 1996, 129, 115 and 259; (b) M. Ghassemzadeh, K. Harms and K. Dehnicke, Z. Naturforsch., 1997, B52, 772; (c) M. Ghassemzadeh, J. Magull, D. Fenske and K. Dehnicke, Z. Naturforsch., 1996, B51, 1579.

18 S. Triguero, R. Llusar, V. Polo and M. Fourmigué, Cryst. Growth Des., 2008, 8, 2241.

19 P. Metrangolo, F. Meyer, T. Pilati, G. Resnati and G. Terraneo, Chem. Commun., 2008, 1635.

20 P. Metrangolo, T. Pilati, G. Terraneo, S. Biella and G. Resnati, CrystEngComm, 2009, 11, 1187.

21 A. Mele, P. Metrangolo, H. Neukirch, T. Pilati and G. Resnati, J. Am. Chem. Soc., 2005, 127, 14972.

22 R. Liantonio, P. Metrangolo, T. Pilati and G. Resnati, Cryst. Growth Des., 2003, 3, 355.

23 S. V. Rosokha, J. Lu, T. Y. Rosokha and J. K. Kochi, Chem. Commun., 2007, 3383.

24 (a) H. M. Yamamoto, J. I. Yamaura and R. Kato, J. Mater. Chem., 1998, 8, 15; (b) H. M. Yamamoto, J. I. Yamaura and R. Kato, J. Am. Chem. Soc., 1998, 120, 5905; (c) H. M. Yamamoto, R. Maeda, J. I. Yamaura and R. Kato, J. Mater. Chem., 2001, 11, 1034; (d) H. M. Yamamoto and R. Kato, Chem. Lett., 2000, 970; (e) Y. Kosaka, H. M. Yamamoto, A. Nakao and R. Kato, Bull. Chem. Soc. Jpn., 2006, 79, 1148. 
25 H. M. Yamamoto, Y. Kosaka, R. Maeda, J. Yamaura, A. Nakao, T. Nakamura and R. Kato, ACS Nano, 2008, 2, 143.

26 H. Bock and S. Holl, Z. Naturforsch, 2002, 57b, 713.

27 H. Bock and S. Holl, Z. Naturforsch, 2002, 57b, 835.

28 H. Bock and S. Holl, Z. Naturforsch, 2002, 57b, 843.

29 S. V. Rosokha, I. S. Neretin, T. Y. Rosokha, J. Hecht and J. K. Kochi, Heteroat. Chem., 2006, 17, 449.

30 P. Munshi, E. Cameron, T. N. Guru Row, J. D. Ferrara and T. S. Cameron, J. Phys. Chem. A, 2007, 111, 7888.

31 A. D. Becke and K. E. J. Edgecombe, J. Chem. Phys., 1990, 92, 5397.

32 B. Silvi and A. Savin, Nature, 1994, 371, 683.

33 A. C. B. Lucassen, A. Karton, G. Leitus, L. J. W. Shimon, J. M. L. Martin and M. E. van der Boom, Cryst. Growth Des., 2007, 7, 386

34 For reviews see: B. Silvi, I. Fourre and M. E. Alikhani, Monatsh. Chem., 2005, 136, 855; V. Polo, J. Andres, S. Berski, L. R. Domingo and B. Silvi, J. Phys. Chem. A, 2008, 112, 7128.

35 S. C. Nyburg and C. H. Faerman, Acta Crystallogr., Sect. B: Struct. Sci. 1985, 41, 274.

36 R. F. W. Bader, Acc. Chem. Res., 1985, 18, 9; R. F. W. Bader, Atoms in Molecules. A Quantum Theory; Claredon Press: Oxford, U.K., 1990.

37 M. E. Alikhani, F. Fuster and B. Silvi, Struct. Chem., 2005, 16, 203.

38 K. Hervé, O. Cador, S. Golhen, K. Costuas, J.-F. Halet, T. Shirahata, T. Muto, T. Imakubo, A. Miyazaki and L. Ouahab, Chem. Mater., 2006, 18, 790.

39 M. Fourmigué and P. Auban-Senzier, Inorg. Chem., 2008, 47, 9979.

40 (a) R. G. Pearson, J. Am. Chem. Soc., 1963, 85, 3533; (b) R. G. Pearson, Adv. Inorg. Chem. Radiochem., 1966, 8, 177; (c) F. Basolo, Coord. Chem. Rev., 1968, 3, 213; (d) J. L. Burmeister, Chem. Rev., 1968, 3, 225.

41 H. Zhang, X. Wang, K. Zhang and B. K. Teo, Coord. Chem. Rev., 1999, 183, 157.

42 T. X. Neenan and G. M. Whitesides, J. Org. Chem., 1988, 53, 2489.

43 H. H. Wenk and W. Sander, Eur. J. Org. Chem., 2002, 3927.
44 SHELX97-Programs for Crystal Structure Analysis (Release 97-2). G. M. Sheldrick, 1998.

45 A. Altomare, M. C. Burla, M. Camalli, G. L. Cascarano, C. Giacovazzo, A. Guagliardi, A. G. G. Moliterni, G. Polidori and R. Spagna, J. Appl. Crystallogr., 1999, 32, 115.

46 L. J. Farrugia, J. Appl. Crystallogr., 1999, 32, 837.

47 M. J. Frisch, G. W. Trucks, H. B. Schlegel, G. E. Scuseria, M. A. Robb, J. R. Cheeseman, J. A. Montgomery, Jr., T. Vreven, K. N. Kudin, J. C. Burant, J. M. Millam, S. S. Iyengar, J. Tomasi, V. Barone, B. Mennucci, M. Cossi, G. Scalmani, N. Rega, G. A. Petersson, H. Nakatsuji, M. Hada, M. Ehara, K. Toyota, R. Fukuda, J. Hasegawa, M. Ishida, T. Nakajima, Y. Honda, O. Kitao, H. Nakai, M. Klene, X. Li, J. E. Knox, H. P. Hratchian, J. B. Cross, V. Bakken, C. Adamo, J. Jaramillo, R. Gomperts, R. E. Stratmann, O. Yazyev, A. J. Austin, R. Cammi, C. Pomelli, J. W. Ochterski, P. Y. Ayala, K. Morokuma, G. A. Voth, P. Salvador, J. J. Dannenberg, V. G. Zakrzewski, S. Dapprich, A. D. Daniels, M. C. Strain, O. Farkas, D. K. Malick, A. D. Rabuck, K. Raghavachari, J. B. Foresman, J. V. Ortiz, Q. Cui, A. G. Baboul, S. Clifford, J. Cioslowski, B. B. Stefanov, G. Liu, A. Liashenko, P. Piskorz, I. Komaromi, R. L. Martin, D. J. Fox, T. Keith, M. A. Al-Laham, C. Y. Peng, A. Nanayakkara, M. Challacombe, P. M. W. Gill, B. Johnson, W. Chen, M. W. Wong, C. Gonzalez, and J. A. Pople, Gaussian 03, Revision C.02, Gaussian, Inc., Wallingford CT, 2004.

48 (a) A. D. Becke, Phys. Rev. A: At., Mol., Opt. Phys., 1988, 38, 3098; (b) A. D. Becke, J. Chem. Phys., 1993, 98, 1372; (c) C. T. Lee, W. T. Yang and R. G. Parr, Phys. Rev. B: Condens. Matter Mater. Phys., 1988, 37, 785.

49 (a) R. Krishnan, J. S. Binkley, R. Seeger and J. A. Pople, J. Chem. Phys., 1980, 72, 650; (b) M. N. Glukhovstev, A. Pross, M. P. McGrath and L. Radom, J. Chem. Phys., 1995, 103, 1878.

50 S. Noury, X. Krokidis, F. Fuster and B. Silvi, Comput. Chem., 1999, 23, 597.

51 Amira 4.0, Template Graphics Software Inc., San Diego, CA, 2002. 